\title{
The Foundation of Stem Cells in the Field of Endodontics
}

\author{
Niladri Maiti ${ }^{1 *}$, Mustafa T. Mohamadamin ${ }^{2}$, Shno Shwan Mahmood ${ }^{2}$, Sara Kawa Ismael $^{2}$ \\ ${ }^{1}$ Associate Professor, Department of Endodontics, Faculty of Dentistry, Tishk International University, Erbil, Iraq \\ ${ }^{2}$ Department of Endodontics, Faculty of Dentistry, Tishk International University, Erbil, Iraq
}

\section{*Corresponding Author}

Niladri Maiti

\section{Article History}

Received: 17.06 .2020

Accepted: 25.06.2020

Published: 29.06.2020

\begin{abstract}
The pulp-dentin complex regenerates the damaged coronal dentin, resorbed root, cervical or apical dentin. Regenerative procedures are to be done with the use of tissue engineering materials, stem cells and suitable biochemical factors that will enhance or replace biological functions. Largely the objective of tissue engineering is the functional restoration of tissue structures. Clinical applications depends on the use of a potential material which would be antiinflammatory, antibacterial and can simultaneously enhance the proliferation and induce the differentiation of the present Dental Pulp Stem Cells (DPSC) into odontoblast-like cells leading to dentin formation. Formation of a reparative dentin layer would provide an optimal barrier to avoid any bacteria infiltration to the pulp tissue, which is not provided by any artificial restorative materials. So application of a scaffold on an open pulp enabling odontoblast-like cells to grow into the scaffold and to convert it into dentin would be an ideal goal. Regenerative endodontics comprises research in adult stem cells, growth factors, organ-tissue culture, and tissue engineering materials.
\end{abstract}

Keywords: Stem cells, Regeneratative Endodontics, tissue regeneration.

\section{INTRODUCTION}

\section{ADULT STEM CELLS}

Regeneration solves medical problems by using living cells as engineering materials. Potential applications include artificial skin comprised of living fibroblasts [1], cartilage repaired with living chondrocytes [2], or other types of cells used in other ways.

The most valuable cells for regenerative medicine are stem cells, with a translational emphasis on the use of postnatal or adult stem cells.

Stem cells hold great promise in regenerative medicine, but there are still many unanswered questions that will have to be addressed before these cells can be routinely used in patients, especially in regard to the safety of the procedure. The potential for pulp-tissue regeneration from implanted stem cells has yet to be tested in animals and clinical trials.

Extensive clinical trials to evaluate efficacy and safety lie ahead before it is likely the Food and Drug Administration (FDA) will approve regenerative endodontic procedures using stem cells.

All tissues originate from stem cells [3]. A stem cell is commonly defined as a cell that has the ability to continuously divide and produce progeny cells that differentiate (develop) into various other types of cells or tissues [4]. Stem cells are commonly defined as either embryonic/fetal or adult/postnatal. We prefer the term embryonic, rather than fetal, because the majority of these cells are embryonic.

\section{PULP STEM CELLS}

Copyright @ 2020: This is an open-access article distributed under the terms of the Creative Commons Attribution license which permits unrestricted use, distribution, and reproduction in any medium for non commercial use (NonCommercial, or CC-BY-NC) provided the original author and source are credited. 
The dental pulp contains a population of stem cells, called pulp stem cells or, in the case of immature teeth, stem cells from human exfoliated deciduous teeth (SHED) Sometimes pulp stem cells are called odontoblastoid cells, because these cells appear to synthesize and secrete dentin matrix like the odontoblast cells they replace [5]. After severe pulp damage or mechanical or caries exposure, the odontoblasts are often irreversibly injured beneath the wound site [6]. Odontoblasts are postmitotic terminally differentiated cells, and cannot proliferate to replace subjacent irreversibly injured odontoblasts. The source of the odontoblastoid cells that replace the odontoblasts and secrete reparative dentin bridges has proven to be controversial.

Initially, the replacement of irreversibly injured odontoblasts by predetermined odontoblastoid cells that do not replicate their DNA after induction was suggested. It was proposed that the cells within the subodontoblast cell-rich layer or zone of Hohl adjacent to the odontoblasts [7] differentiate into odontoblastoids. However, the purpose of these cells appears to be limited to an odontoblast-supporting role, as the survival of these cells was linked to the survival of the odontoblasts and no proliferative or regenerative activity was observed.

The use of tritiated thymidine to study cellular division in the pulp by autoradiography after damage [8] revealed a peak in fibroblast activity close to the exposure site about 4 days after successful pulp capping of monkey teeth. An additional autoradiographic study of dentin bridge formation in monkey teeth, after calcium hydroxide direct pulp capping for up to 12 days [9], has revealed differences in the cellular labeling depending on the location of the wound site. Labeling of specific cells among the fibroblasts and perivascular cells shifted from low to high over time if the exposure was limited to the odontoblastic layer and the cell-free zone, whereas labeling changed from high to low if the exposure was deep into the pulpal tissue. More cells were labeled close to the reparative dentin bridge than in the pulp core.

The autoradiographic findings did not show any labeling in the existing odontoblast layer, or in a specific pulp location. This provided support for the theory that the progenitor stem cells for the odontoblastoid cells are resident undifferentiated mesenchymal cells [10].

The origins of these cells may be related to the primary odontoblasts, because during tooth development, only the neural crest- derived cell population of the dental papilla is able to specifically respond to the basement membranemediated inductive signal for odontoblast differentiation [11].

The ability of both young and old teeth to respond to injury by induction of reparative dentinogenesis suggests that a small population of competent progenitor pulp stem cells may exist within the dental pulp throughout life. However, the debate on the nature of the precursor pulp stem cells giving rise to the odontoblastoid cells, as well as questions concerning the heterogeneity of the dental pulp population in adult teeth, remain to be resolved [12]. Information on the mechanisms by which these cells are able to detect and respond to tooth injury is scarce, but this information will be valuable for use in developing tissue engineering and regenerative endodontic therapies.

One of the most significant obstacles to overcome in creating replacement pulp tissue for use in regenerative endodontics is to obtain progenitor pulp cells that will continually divide and produce cells or pulp tissues that can be implanted into root canal systems.

Possibilities are the development of an autogenous human pulp stem cell line that is disease- and pathogen-free, and/or the development of a tissue biopsy transplantation technique using cells from the oral mucosa, as examples.

The use of a human pulp stem cell line has the advantage that patients do not need to provide their own cells through a biopsy, and that pulp tissue constructs can be premade for quick implantation when they are needed. If a patient provides their own tissue to be used to create a pulp tissue construct, it is possible that the patient will have to wait some time until the cells have been purified and/or expanded in number. This latter point is based on the finding that many adult tissues contain only 1 to $4 \%$ stem cells [13], so purification is needed, and expansion of cell numbers would permit collection of smaller tissue biopsies. Alternatively, larger sources of autologous tissue might be required. The sourcing of stem cells to be used in endodontic, dental, and medical therapies is a significant limiting factor in the development of new therapies and should be a major research priority.

\section{STEM CELL IDENTIFICATION}

Stem cells can be identified and isolated from mixed cell populations by four commonly used techniques:

a) Staining the cells with specific antibody markers and using a flow cytometer, in a process called fluorescent antibody cell sorting (FACS);

b) Immunomagnetic bead selection;

c) Immunohistochemical staining; and 
d) Physiological and Histological criteria, including phenotype (appearance), chemotaxis, proliferation, differentiation, and mineralizing activity.

FACS together with the protein marker CD34 is widely used to separate human stem cells expressing CD34 from peripheral blood, umblical cord blood, and cell cultures [14].

Different types of stem cells often express different proteins on their membranes and are therefore not identified by the same stem cell protein marker. The most studied dental stem cells are those of the dental pulp. Human pulp stem cells express von

Willebrand factor CD146, alpha-smooth muscle actin, and 3G5 proteins [15]. Human pulp stem cells also have a fibroblast phenoptype, with specific proliferation, differentiation, and mineralizing activity patterns.

\section{GROWTH FACTORS}

Growth factors are proteins that bind to receptors on the cell and induce cellular proliferation and/or differentiation

Many growth factors are quite versatile, stimulating cellular division in numerous cell types, while others are more cell specific. The names of individual growth factors often have little to do with their most important functions and exist because of the historical circumstances under which they arose.

For example, fibroblast growth factor (FGF) was found in a cow brain extract by Gospadarowicz and colleagues [16] and tested in a bioassay which caused fibroblasts to proliferate.

Currently, a variety of growth factors have been identified, with specific functions that can be used as part of stem cell and tissue engineering therapies [17].

Many growth factors can be used to control stem cell activity, such as by increasing the rate of proliferation, inducing differentiation of the cells into another tissue type, or stimulating stem cells to synthesize and secrete mineralized matrix.

A summary of the source, activity and usefulness of common growth factors is shown in the Table-1:

Table-1: The source, activity and usefulness of common growth factors

\begin{tabular}{|c|c|c|c|c|}
\hline Abbreviation & Factor & Primary source & Activity & Usefulness \\
\hline BMP & $\begin{array}{l}\text { Bone morphogenetic } \\
\text { proteins }\end{array}$ & Bone matrix & $\begin{array}{l}\text { BMP induces differentiation of } \\
\text { osteoblasts and } \\
\text { mineralization of bone }\end{array}$ & $\begin{array}{l}\text { BMP is used to make stem } \\
\text { cells synthesize and secrete } \\
\text { mineral matrix }\end{array}$ \\
\hline CSF & $\begin{array}{l}\text { Colony stimulating } \\
\text { factor }\end{array}$ & A wide range of cells & $\begin{array}{l}\text { CSFs are cytokines that stimulate } \\
\text { the proliferation of specific } \\
\text { pluripotent bone stem cells }\end{array}$ & $\begin{array}{l}\text { CSF can be used to increase } \\
\text { stem cell numbers }\end{array}$ \\
\hline EGF & $\begin{array}{l}\text { Epidermal growth } \\
\text { factor }\end{array}$ & Submaxillary glands & $\begin{array}{l}\text { EGF promotes proliferation of } \\
\text { mesenchymal, glial and epithelial } \\
\text { cells }\end{array}$ & $\begin{array}{l}\text { EGF can be used to } \\
\text { increase stem cell } \\
\text { numbers }\end{array}$ \\
\hline FGF & $\begin{array}{l}\text { Fibroblast growth } \\
\text { factor }\end{array}$ & A wide range of cells & $\begin{array}{l}\text { FGF promotes proliferation of } \\
\text { many cells }\end{array}$ & $\begin{array}{l}\text { FGF can be used to increase } \\
\text { stem cell numbers }\end{array}$ \\
\hline IGF & $\begin{array}{l}\text { Insulin-like growth } \\
\text { factor-I or II }\end{array}$ & I - liver II-variety of cells & $\begin{array}{l}\text { IGF promotes proliferation of } \\
\text { many cell types }\end{array}$ & $\begin{array}{l}\text { IGF can be used to increase } \\
\text { stem cell numbers }\end{array}$ \\
\hline $\mathrm{IL}$ & $\begin{array}{l}\text { Interleukins IL-1 to } \\
\text { IL-13 }\end{array}$ & Leukocytes & $\begin{array}{l}\text { IL are cytokines which } \\
\text { stimulate the humoral and cellular } \\
\text { immune responses }\end{array}$ & $\begin{array}{l}\text { Promotes inflammatory cell } \\
\text { activity }\end{array}$ \\
\hline PDGF & $\begin{array}{l}\text { Platelet-derived } \\
\text { growth factor }\end{array}$ & $\begin{array}{l}\text { Platelets, endothelial } \\
\text { cells, } \\
\text { placenta }\end{array}$ & $\begin{array}{l}\text { PDGF promotes proliferation } \\
\text { of connective tissue, glial and } \\
\text { smooth muscle cells }\end{array}$ & $\begin{array}{l}\text { PDGF can be used to } \\
\text { increase stem cell } \\
\text { numbers }\end{array}$ \\
\hline TGF-_ & $\begin{array}{l}\text { Transforming } \\
\text { Growth factoralpha }\end{array}$ & $\begin{array}{l}\text { Macrophages, brain cells, } \\
\text { and keratinocytes }\end{array}$ & $\begin{array}{l}\text { TGF-_ may be important for } \\
\text { normal wound healing }\end{array}$ & $\begin{array}{l}\text { Induces epithelial and } \\
\text { tissue structure development }\end{array}$ \\
\hline TGF-_ & $\begin{array}{l}\text { Transforming } \\
\text { growth factor-beta }\end{array}$ & $\begin{array}{l}\text { Dentin matrix, activated } \\
\text { TH1 cells (T-helper) and } \\
\text { natural killer (NK) cells }\end{array}$ & $\begin{array}{l}\text { TGF-_ is anti-inflammatory, } \\
\text { promotes wound healing, inhibits } \\
\text { macrophage and lymphocyte } \\
\text { proliferation }\end{array}$ & $\begin{array}{l}\text { TGF-_ } 1 \text { is present in dentin } \\
\text { matrix and has been used to } \\
\text { promote mineralization of pulp } \\
\text { tissue }\end{array}$ \\
\hline NGF & Nerve growth factor & $\begin{array}{l}\text { A protein secreted by a } \\
\text { neuron's target tissue }\end{array}$ & $\begin{array}{l}\text { NGF is critical for the survival } \\
\text { and maintenance of sympathetic } \\
\text { and sensory neurons. }\end{array}$ & $\begin{array}{l}\text { Promotes neuron } \\
\text { outgrowth and neural cell } \\
\text { survival }\end{array}$ \\
\hline
\end{tabular}

\section{Root Canal Revascularization via Blood Clotting}


Several case reports have documented revascularization of necrotic root canal systems by disinfection followed by establishing bleeding into the canal system via overinstrumentation [18].

An important aspect of these cases is the use of intracanal irrigants ( $\mathrm{NaOCl}$ and chlorhexdine) with placement of antibiotics (e.g. a mixture of ciprofloxacin, metronidazole, and minocycline paste) for several weeks.

This particular combination of antibiotics effectively disinfects root canal systems [19] and increases revascularization of avulsed and necrotic teeth, suggesting that this is a critical step in revascularization.

The selection of various irrigants and medicaments is worthy of additional research, because these materials may confer several important effects for regeneration in addition to their antimicrobial properties.

For example, tetracycline enhances the growth of host cells on dentin, not by an antimicrobial action, but via exposure of embedded collagen fibers or growth factors [20]. However, it is not yet know if minocycline shares this effect and whether these additional properties might contribute to successful revascularization.

Although these case reports are largely from teeth with incomplete apical closures, it has been noted that reimplantation of avulsed teeth with an apical opening of approximately $1.1 \mathrm{~mm}$ demonstrate a greater likelihood of revascularization [21].

This finding suggests that revascularization of necrotic pulps with fully formed (closed) apices might require instrumentation of the tooth apex to approximately 1 to $2 \mathrm{mmin}$ apical diameter to allow systemic bleeding into root canal systems.

Clearly, the development of regenerative endodontic procedures may require reexamination of many of the closely held precepts of traditional endodontic procedures. The revascularization method assumes that the root canal space has been disinfected and that the formation of a blood clot yields a matrix (e.g., fibrin) that traps cells capable of initiating new tissue formation.

It is not clear that the regenerated tissue's phenotype resembles dental pulp; however, case reports published to date do demonstrate continued root formation and the restoration of a positive response to thermal pulp testing [18].

Another important point is that younger adult patients generally have a greater capacity for healing [22].

\section{Advantages}

There are several advantages to a revascularization approach.

- First, this approach is technically simple and can be completed using currently available instruments and medicaments without expensive biotechnology.

- Second, the regeneration of tissue in root canal systems by a patient's own blood cells avoids the possibility of immune rejection and pathogen transmission from replacing the pulp with a tissue engineered construct.

\section{Several concerns need to be addressed in prospective research are the followings}

First, the case reports of a blood clot having the capacity to regenerate pulp tissue are exciting, but caution is required, because the source of the regenerated tissue has not been identified.

Animal studies and more clinical studies are required to investigate the potential of this technique before it can be recommended for general use in patients. Generally, tissue engineering does not rely on blood clot formation, because the concentration and composition of cells trapped in the fibrin clot is unpredictable. This is a critical limitation to a blood clot revascularization approach, because tissue engineering is founded on the delivery of effective concentrations and compositions of cells to restore function. It is very possible that variations in cell concentration and composition, particularly in older patients (where circulating stem cell concentrations may be lower) may lead to variations in treatment outcome.

On the other hand, some aspects of this approach may be useful; plasma-derived fibrin clots are being used for development as scaffolds in several studies [23].

Second, enlargement of the apical foramen is necessary to promote vascularizaton and to maintain initial cell viability via nutrient diffusion. 
Related to this point, cells must have an available supply of oxygen; therefore, it is likely that cells in the coronal portion of the root canal system either would not survive or would survive under hypoxic conditions before angiogenesis.

Interestingly, endothelial cells release soluble factors under hypoxic conditions that promote cell survival and angiogenesis, whereas other cell types demonstrate similar responses to low oxygen availability [24].

\section{Pulp Implantation}

The majority of in vitro cell cultures grow as a single monolayer attached to the base of culture flasks. However, some stem cells do not survive unless they are grown on top of a layer of feeder cells [25].

In all of these cases, the stem cells are grown in two dimensions. In theory, to take two-dimensional cell cultures and make them three-dimensional, the pulp cells can be grown on biodegradable membrane filters.

Many filters will be required to be rolled together to form a threedimensional pulp tissue, which can be implanted into disinfected root canal systems.

\section{Advantages}

The advantages of this delivery system are that the cells are relatively easy to grow on filters in the laboratory.

The growth of cells on filters has been accomplished for several decades, as this is how the cytotoxicity of many test materials is evaluated [26].

- Moreover, aggregated sheets of cells are more stable than dissociated cells administered by injection into empty root canal systems.

The potential problems associated with the implantation of sheets of cultured pulp tissue is that specialized procedures may be required to ensure that the cells properly adhere to root canal walls.

Sheets of cells lack vascularity, so only the apical portion of the canal systems would receive these cellular constructs, with coronal canal systems filled with scaffolds capable of supporting cellular proliferation [27].

Because the filters are very thin layers of cells, they are extremely fragile, and this could make them difficult to place in root canal systems without breakage.

In pulp implantation, replacement pulp tissue is transplanted into cleaned and shaped root canal systems.

The source of pulp tissue may be a purified pulp stem cell line that is disease or pathogen-free, or is created from cells taken from a biopsy, that has been grown in the laboratory. The cultured pulp tissue is grown in sheets in vitro on biodegradable polymer nanofibers or on sheets of extracellular matrix proteins such as collagen I or fibronectin. So far, growing dental pulp cells on collagens I and III has not proved to be successful [28], but other matrices, including vitronectin and laminin, require investigation.

The advantage of having the cells aggregated together is that it localizes the postnatal stem cells in the root canal system.

The disadvantage of this technique is that implantation of sheets of cells may be technically difficult.

The sheets are very thin and fragile, so research is needed to develop reliable implantation techniques.

The sheets of cells also lack vascularity, so they would be implanted into the apical portion of the root canal system with a requirement for coronal delivery of a scaffold capable of supporting cellular proliferation.

Cells located more than $200 \_\mathrm{m}$ from the maximum oxygen diffusion distance from a capillary blood supply are at risk of anoxia and necrosis [29].

The development of this endodontic tissue engineering therapy appears to present low health hazards to patients, although concerns over immune responses and the possible failure to form functioning pulp tissue must be addressed through careful in vivo research and controlled clinical trials. 


\section{CONCLUSION}

The clinical success rates of endodontic treatments can exceed 90\% [30]. However, many teeth are not given the opportunity to be saved by endodontic treatment and instead are extracted, with subsequent placement of an artificial prosthesis, such as an implant.

However, for regenerative endodontic procedures to be widely available and predictable, endodontists will have to depend on tissue engineering therapies to regenerate pulp dentin tissue.

The proposed therapies involving stem cells, growth factors, and tissue engineering all require pulp revascularization, in itself an enormous challenge.

One of the most challenging aspects of developing a regenerative endodontic therapy is to understand how the various component procedures can be optimized and integrated to produce the outcome of a regenerated pulp-dentin complex.

\section{REFERENCES}

1. Raguse, J. D., \& Gath, H. J. (2005). A metabolically active dermal replacement (Dermagraft) for vestibuloplasty. Journal of oral rehabilitation, 32(5), 337-340.

2. Song, S. U., Cha, Y. D., Han, J. U., Oh, I. S., Choi, K. B., Yi, Y., ... \& Ganjei, J. K. (2005). Hyaline cartilage regeneration using mixed human chondrocytes and transforming growth factor- $\beta 1$-producing chondrocytes. Tissue engineering, 11(9-10), 1516-1526.

3. Smith, A. G. (2001). Embryo-derived stem cells: of mice and men. Annual review of cell and developmental biology, 17(1), 435-462.

4. Rao, M. S. (2004). Stem sense: a proposal for the classification of stem cells. Stem cells and development, 13(5), 452-455.

5. Kitasako, Y., Shibata, S., Pereira, P. N., \& Tagami, J. (2000). Short-term dentin bridging of mechanically-exposed pulps capped with adhesive resin systems. Operative dentistry, 25(3), 155-162.

6. Murray, P. E., Hafez, A. A., Smith, A. J., Windsor, L. J., \& Cox, C. F. (2003). Histomorphometric analysis of odontoblast-like cell numbers and dentine bridge secretory activity following pulp exposure. International endodontic journal, 36(2), 106-116.

7. Höhl, E. (1896). Beitrag zur histologie der pulpa und des dentins. Archives Anatomic Physiologie 32: 31-54.

8. Feit, J., Metelova, M., \& Sindelka, Z. (1970). Incorporation of $3 \mathrm{H}$ thymidine into damaged pulp of rat incisors. Journal of dental research, 49(4), 783-786.

9. Fitzgerald, M., Chiego Jr, D. J., \& Heys, D. R. (1990). Autoradiographic analysis of odontoblast replacement following pulp exposure in primate teeth. Archives of oral biology, 35(9), 707-715.

10. Ruch, J. V. (1990). Patterned distribution of differentiating dental cells: facts and hypotheses. Journal de biologie buccale, 18(2), 91-98.

11. Yamamura, T. (1985). Differentiation of pulpal cells and inductive influences of various matrices with reference to pulpal wound healing. Journal of Dental Research, 64(4), 530-540.

12. Goldberg, M., \& Lasfargues, J. J. (1995). Pulpo-dentinal complex revisited. Journal of dentistry, 23(1), 15-20.

13. Poulsom, R., Alison, M. R., Forbes, S. J., \& Wright, N. A. (2002). Adult stem cell plasticity. The Journal of Pathology: A Journal of the Pathological Society of Great Britain and Ireland, 197(4), 441-456.

14. Gajkowska, A., Oldak, T., Jastrzewska, M., Machaj, E. K., Walewski, J., Kraszewska, E., \& Pojda, Z. (2006). Flow cytometric enumeration of CD34+ hematopoietic stem and progenitor cells in leukapheresis product and bone marrow for clinical transplantation: a comparison of three methods. Folia Histochemica et Cytobiologica, 44(1), 5360 .

15. Shi, S., \& Gronthos, S. (2003). Perivascular niche of postnatal mesenchymal stem cells in human bone marrow and dental pulp. Journal of bone and mineral research, 18(4), 696-704.

16. Gospodarowicz, D. E. N. I. S. (1975). Purification of a fibroblast growth factor from bovine pituitary. Journal of Biological Chemistry, 250(7), 2515-2520.

17. Einhorn, MD, FACP, FACE, D. (2003). American College of Endocrinology position statement on the insulin resistance syndrome. Endocrine practice, 9(Supplement 2), 5-21.

18. Banchs, F., \& Trope, M. (2004). Revascularization of immature permanent teeth with apical periodontitis: new treatment protocol?. Journal of endodontics, 30(4), 196-200.

19. Sato, I., Ando- Kurihara, N., Kota, K., Iwaku, M., \& Hoshino, E. (1996). Sterilization of infected root- canal dentine by topical application of a mixture of ciprofloxacin, metronidazole and minocycline in situ. International endodontic journal, 29(2), 118-124. 
20. Terranova, V. P., Odziemiec, C., Tweden, K. S., \& Spadone, D. P. (1989). Repopulation of dentin surfaces by periodontal ligament cells and endothelial cells: effect of basic fibroblast growth factor. Journal of periodontology, 60(6), 293-301.

21. Kling, M., Cvek, M., \& Mejare, I. (1986). Rate and predictability of pulp revascularization in therapeutically reimplanted permanent incisors. Dental Traumatology, 2(3), 83-89.

22. Amler, M. H. (1977). The age factor in human extraction wound healing. Journal of Oral Surgery (American Dental Association: 1965), 35(3), 193-197.

23. Llames, S. G., Del Rio, M., Larcher, F., García, E., García, M., Escamez, M. J., ... \& Meana, A. (2004). Human plasma as a dermal scaffold for the generation of a completely autologous bioengineered skin. Transplantation, 77(3), 350-355.

24. Kim, Y. J., Lenke, L. G., Bridwell, K. H., Cho, Y. S., \& Riew, K. D. (2004). Free hand pedicle screw placement in the thoracic spine: is it safe?. Spine, 29(3), 333-342.

25. Ulloa-Montoya, F., Verfaillie, C. M., \& Hu, W. S. (2005). Culture systems for pluripotent stem cells. Journal of bioscience and bioengineering, 100(1), 12-27.

26. Roulet, J. F. (1994). Marginal integrity: clinical significance. Journal of Dentistry, 22(Suppl 2): S9-S12.

27. Peter, S. J., Miller, M. J., Yasko, A. W., Yaszemski, M. J., \& Mikos, A. G. (1998). Polymer concepts in tissue engineering. Journal of biomedical materials research, 43(4), 422-427.

28. Huang, G. T. J., Sonoyama, W., Chen, J., \& Park, S. H. (2006). In vitro characterization of human dental pulp cells: various isolation methods and culturing environments. Cell and tissue research, 324(2), 225.

29. Helmlinger, G., Yuan, F., Dellian, M., \& Jain, R. K. (1997). Interstitial pH and pO 2 gradients in solid tumors in vivo: high-resolution measurements reveal a lack of correlation. Nature medicine, 3(2), 177-182.

30. Lazarski, M. P., Walker III, W. A., Flores, C. M., Schindler, W. G., \& Hargreaves, K. M. (2001). Epidemiological evaluation of the outcomes of nonsurgical root canal treatment in a large cohort of insured dental patients. Journal of endodontics, 27(12), 791-796. 